\title{
Faktor yang Mempengaruhi Kepuasan Tinggal Pada Rusunawa di Kota Surabaya
}

\author{
Rita Ernawati \\ Program Studi Arsitektur, Universitas Islam Negeri Sunan Ampel, Surabaya, Indonesia \\ rita_ernawati@uinsby.ac.id \\ doi.org/ 10.29080/eija.v5i1.527
}

\begin{abstract}
Residential satisfaction is a result of the interaction between the personal characteristics and the physical characteristics of the inhabit house. Personal characteristics that bring out the expectations of a place to live. Factors that generally affect satisfaction with a place to live are location, economy, facilities, quality of buildings and social life with other residents. Rusunawa is a form of residence. But Rusunawa also provides solutions for housing provision in Indonesia. To ensure the suitability and comfort of residents, this research tries to classify factors that increase the satisfaction of living in Rusunawa. Applying qualitative collection methods and analyse is done by triangulation for research credibility. Surveys with questionnaires, observations, interviews and Focus Group Discussions were conducted to produce diverse data, so it could be analyzed with theory and further research. The results of this research indicate that location, economic, technical building and social life factors are factors that influence the satisfaction of stay. Technical factors related to occupancy area and building management still need to be improved in order to meet the occupant satisfaction.
\end{abstract}

Keywords: housing satisfaction, low-cost housing, low-income communities

Abstrak: Kepuasan terhadap tempat tinggal merupakan hasil dari interaksi karakteristik individual dengan karakteristik fisik rumah yang dihuninya. Karakteristik personal suatu individu memunculkan ekspetasi terhadap tempat tinggal. Faktor yang secara umum mempengaruhi kepuasan terhadap tempat tinggal adalah lokasi, ekonomi, fasilitas, kualitas bangunan dan kehidupan sosial dengan penghuni lain. Rusunawa merupakan bentuk tempat tinggal dengan kompleksitas permasalahan tersendiri. Namun rusunawa juga dianggap mampu memberikan solusi bagi peyediaan perumahan di Indonesia. Untuk menjamin kelayakan dan kenyamanan penghuni, penelitian ini mencoba mengelaborasi faktor yang mempengaruhi kepuasan tinggal di rusunawa. Dengan metode kualitatif, pengumpulan dan analisis dilakukan secara triangulasi untuk menjamin kredibilitas penelitian. Survei dengan kuesioner, observasi, wawancara dan Focus Group Discussion dilakukan untuk menghasilkan data yang beragam agar dapat dianalisis dengan teori dan penelitian terdahulu. Hasil penelitian ini menunjukkan bahwa faktor lokasi, ekonomi, teknis bangunan dan kehidupan sosial merupakan faktor yang mempengaruhi kepuasan tinggal. Faktor teknis yang meliputi luas hunian dan pengelolaan bangunan masih perlu ditingkatkan untuk memenuhi kepuasan penghuni.

Kata Kunci: kepuasan tempat tinggal, rusunawa, masyarakat berpenghasilan rendah

\section{PENDAHULUAN}

Preferensi bermukim tidak hanya ditentukan oleh kondisi tempat tinggal namun juga keadaan lingkungan sekitar. Pada kelompok masyarakat menengah keatas keadaan lingkungan sekitar menjadi pertimbangan karena berkaitan dengan karakteristik mereka. Sedangkan pada masyarakat berpenghasilan rendah masih belum mempertimbangkan keadaan lingkungan karena berfokus mendapatkan tempat bermukim. Faktor lokasi menjadi pertimbangan penting bagi masyarakat berpenghasilan rendah terkait kemudahan akses ke tempat kerja dan beragam kebutuhan fasilitas menyatu dengan komunitas sekitar (Turner, 1976).
Pendapat Turner (1976) sejalan dengan Rapoport (2016) yang menyatakan penentuan lokasi tempat tinggal berkaitan dengan karakteristik hunian, status, homogenitas sosial, kondisi lingkungan, ketersediaan sarana prasarana dan kehidupan sosial. Pemilihan tempat tinggal didasarkan pada pemahaman karakteristik orang dan lingkungannya. Permasalahan timbul karena tidak adanya pilihan tempat tinggal terutama yang sesuai kemampuan mereka, terutama pada masyarakat berpenghasilan rendah. Beradaptasi terhadap kondisi yang ada dilakukan untuk meminimalisasi ketidaksesuaian (Rapoport, 2016). Rusunawa (Rumah Susun Sewa) merupakan salah 
satu program pemerintah dalam menyediakan tempat tinggal bagi masyarakat berpenghasilan rendah. Pembangunan rusunawa oleh pemerintah tidak terlepas dari beragam permasalahan baik pada proses pembangunan maupun pengelolaan. Salah satu aspek yang menjadikan keberhasilan pembangunan rusunawa adalah kepuasan penghuni tinggal di rusun. Secara teori karakteristik fisik dan non fisik rusun mempengaruhi kepuasan tinggal di rusun.

Kepuasan terhadap tempat tinggal merupakan hasil dari interaksi karakteristik individual dengan karakteristik fisik rumah yang dihuninya. Karakteristik personal suatu individu memunculkan harapan (expectations), harapan tersebut bervariasi karena dipengaruhi oleh tingkat pendapatan, pendidikan dan struktur keluarga. Atribut kualitas bangunan yang baik, kelengkapan sarana dan prasarana, hubungan yang baik antar penghuni dan dengan pengelola menjadi faktor yang mempengaruhi kepuasan penghuni (Paris \& Kangari, 2005). Karakteristik rusun yang mempengaruhi kepuasan tinggal diantaranya adalah tarif sewa, kualitas fisik bangunan, kelengkapan sarana \& prasarana, lokasi, kualitas pelayanan dan pengelolaan rusun (Greene \& Ortúzar, 2002).

Kota Surabaya merupakan Kota Surabaya sebagai salah satu kota metropolitan di Indonesia memiliki rusunawa yang tersebar di beberapa wilayah baik yang berdekatan dengan kawasan industri. $\mathrm{Di}$ tengah pesatnya pertumbuhan industri, rusunawa di Kota Surabaya mampu menjadi alternatif solusi menyediakan hunian terjangkau bagi pekerja pabrik, melalui perencanaan yang konprehensif dan partisipatif dengan melibatkan segenap pemangku kepentingan. Kualitas hunian rusun harus baik, lokasi dengan jarak yang terjangkau, serta kondisi sarana dan prasarana yang mendukung produktivitas pekerja (Sofyan, 2006).

Penelitian lain yang dilakukan pada rusunawa di Kota Surabaya banyak dilakukan dalam konteks kebijakan dan pengelolaan. Irkham \& Utomo (2017) meneliti terkait penetapan harga sewa yang terjangkau bagi penghuni rusun. Tondok, Oesmani, \& Tonny, (2012) meneliti secara fenomenologi terkait kehidupan di penghuni rusun yang beralih dari landed housing menjadi vertical housing. Sedangkan Zahro (2016) melakukan penelitian terkait kepuasan pengelolaan rusun oleh Dinas Pengalolaan Bangunan dan Tanah Kota Surabaya.

\subsection{Kepuasan terhadap Tempat Tinggal}

Keberadaan lingkungan dengan sarana dan prasarana yang baik dan lengkap membuat masyarakat betah untuk tinggal sehingga kecenderungan pindah semakin kecil (Widiastomo, 2014). Hasil penelitian menunjukkan bahwa kualitas lingkungan secara signifikan memiliki pengaruh besar terhadap kepuasan penghuni di Perumnas Bukit Sendangmulyo.

Menurut Rahman \& Rahdriawan (2017) dalam penelitiannya di Semarang menyatakan bahwa kondisi rumah berpengaruh signifikan terhadap kepuasan penghuni. Penelitian ini merumuskan bahwa secara umum tingkat kepuasan penghuni perumahan Grand Tembalang Regency Semarang cukup baik. Pada penelitian di Perum Perumnas yang dilakukan oleh Dafrimon \& Tanzil (2012) menyebutkan bahwa pada dimensi tangibles penghuni Perum Perumnas sudah merasa sangat puas dengan lokasi yang strategis dan transportasi umum yang tersedia. Pada dimensi reliability penghuni Perum Perumnas sudah merasa puas terhadap pelayanan petugas yang tepat waktu. Pada dimensi responsiveness penghuni Perum Perumnas tidak menemukan kepuasan terhadap petugas dalam membantu penghuni..

Pada dimensi assurance penghuni Perum Perumnas merasa puas atas tingkah laku yang sopan, ramah dan memiliki rasa hormat. Pada dimensi emphaty penghuni Perum Perumnas tidak menemukan rasa puas terhadap hal-hal yang berkaitan perhatian secara individu dan kebutuhan penghuni, karena semua nilai berada dibawah kesenjangan dan tingkat kepuasan yang ditentukan.

Variabel yang digunakan dalam penelitian ini mengacu pada beberapa pendapat. Menurut Greene \& Ortúzar (2002) variabel kepuasan tinggal meliputi (1) lokasi (2) sanitasi dan kenyamanan (3) fasilitas yang terdapat di kota (4) layanan jasa yang tersedia di kota (5) bentuk hunian (6) kecukupan ruang hunian. Sedangkan menurut Hui (1999) terdapat empat atribut rusunawa (rental housing attribute), unit bangunannya (ukuran dan kondisi bangunan), lokasi (aksesibilitas), lingkungan sosial (karakteristik fisik dan sosial), dan layanan jasa yang diberikan badan pengelola.

Dalam mengidentifikasi faktor yang mempengaruhi kepuasan tempat tinggal Mohit \& Raja (2014) mendasarkan pada empat faktor yaitu (1) karakteristik sosial demografi penghuni yang dijabarkan menjadi variabel umur, pendapatan, lama tinggal, status kepemilikan, dan tipe rumah tangga; (2) karakteristik hunian meliputi variabel jumlah kamar tidur dan toilet, ukuran dan letak dapur, kualitas bangunan rumah; dan (3) karakteristik lingkungan sekitar meliputi variabel lokasi terhadap fasilitas umum seperti tempat kerja, sekolah, pusat kesehatan dan pusat perbelanjaan.

Dalam kontek penyediaan perumahan di Malaysia diantara ketiga faktor tersebut yang signifikan mempengaruhi kepuasan tempat tinggal adalah karakteristik lingkungan sekitar. Keragaman kondisi sosial demografi penghuni dan kondisi hunian tidak berpengaruh secara signifikan terhadap kepuasan penghuni. Perilaku penghuni menunjukkan preferensi 
untuk beradaptasi terhadap kondisi tempat tinggal sebagai refleksi kepuasan mereka. (Mohit \& Raja, 2014).

\subsection{Penelitian Terdahulu Terkait Kepuasan terhadap Rusunawa}

Penelitian terkait tingkat kepuasan penghuni rusunawa dilakukan dalam beragam konteks. Secara umum hasil penelitian terdahulu menunjukkan bahwa rusunawa belum mampu memberikan kepuasan tinggal bagi penghuni. Hasil penelitian pada dua lokasi rusunawa di Jakarta yaitu Rusunawa Kemayoran dan Cengkareng menunjukkan ketidakpuasan penghuni terhadap pengelolaan rusun. Tidak hanya pada kedua lokasi tersebut, indikasi ketidakpuasan juga ditemukan pada beberapa rusunawa lain seperti rusunawa Martubung di Medan, Rusun Sleman di Yogyakarta. Pada umumnya, faktor penyebab ketidakpuasan penghuni terkait kebijakan kenaikan tarif, lokasi rusun jauh dari tempat kerja, kualitas bangunan yang tidak memenuhi standar, dan pemeliharaan yang tidak optimal (Setiadi, 2014). (Hidayati, (2017) dalam penelitiannya pada rusunawa di Surakarta terkait kepuasan pada aspek fisik dan lingkungan menunjukkan bahwa kurang optimalnya penyediaan sarana dan prasarana pada rusunawa untuk memenuhi kebutuhan bermukim bagi penghuni. Aspek yang sangat krusial adalah terkait keterbatasan ruang pada unit hunian rusun.

\section{METODE PENELITIAN}

Penelitian kualitatif merupakan penelitian yang bermaksud untuk memahami fenomena terkait persepsi, motivasi, tindakan, secara holistik, dan dengan cara deskripsi dalam bentuk kata-kata dan bahasa, pada suatu konteks khusus yang alamiah dan dengan memanfaatkan berbagai metode alamiah (Moleong, 2005, Sugiono, 2005). Penelitian terkait kepuasan tinggal di rusunawa dilakukan dengan mengeksplorasi fenomena persepsi dan motivasi penghuni dalam konteks alami. Peneliti mencoba merumuskan faktor berdasarkan penjelasan penghuni secara mendalam melalui beragam teknik pengumpulan data dan analisis sehingga relevan menerapkan metode penelitian kualitatif. Pengumpulan data dilakukan secara triangulasi dengan menerapkan terknik survei dengan kuesioner, observasi, dan wawancara mendalam. Pada tahapan analisis dilakukan proses pengorganisasian dan pengkategorisasian data untuk dianalisis secara kuantitatif deskriptif. Hasi wawancara medalam dianalisis dengan mengelompokkan dalam tema yang sama. Analisis triangulasi dilakukan dengan mendiskusikan data kuesioner, wawancara mendalam dengan teori yang relevan. Pada tahap akhir dirumuskan argumentasi penelitian untuk menjawab permasalahan penelitian.

\section{HASIL DAN PEMBAHASAN}

\subsection{Gambaran Umum Rusunawa}

Rusunawa Warugunung merupakan rumah susun sederhana sewa yang dibangun pada tahun 1996 oleh Perum Perumnas. Menempati lahan milik Pemerintah Kota Surabaya seluas $3 \mathrm{Ha}$ di Jalan Mastrip No.7, Kelurahan Warugunung, Kecamatan Karang Pilang. Terdiri dari 10 blok yang masing-masing terdiri dari 5 lantai, dengan total hunian sebanyak 480 unit, ruang usaha 92 unit dan fasilitas umum 28 unit. Sasaran penghuni Rusunawa Warugunung adalah karyawan/buruh industri yang bekerja di sekitar wilayah ini. Rusun Warugunung berdekatan dengan banyak pabrik-pabrik industri sehingga sebagian besar penghuni rusun merupakan pekerja pabrik.

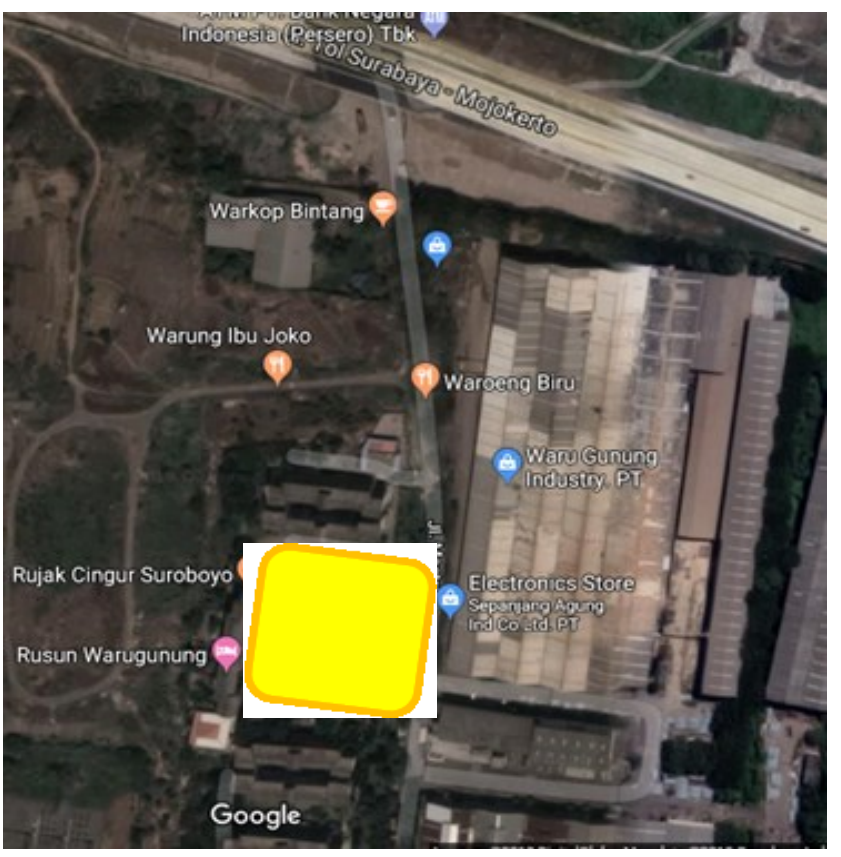

Gambar 1. Lokasi Rusunawa Warugunung (Sumber: Google Maps, 2018)

\subsection{Gambaran Kondisi Bangunan Rusun}

Rusunawa (Rumah Susun Sewa) Warugunung merupakan rusunawa dengan warga berpenghasilan menengah kebawah yang dikelola oleh Dinas Pengelolaan Bangunan dan Tanah. Rusunawa yang berada di Warugunung dibangun dengan 2 tahap pembangunan. Tahap pertama dibangun tahun 1996 sebanyak 4 Blok, lalu dilanjut tahap kedua pada tahun 1997 dengan tambahan 6 Blok. Rumah susun Warugunung memiliki luas sekitar 3 hektar dan memiliki 10 blok yang setiap unit terdiri dari satu kamar tidur, dapur dan satu kamar mandi. Setiap blok berjumlah 5 lantai yaitu lantai satu yang digunakan untuk sarana parkir, aula, tempat pendidikan, ruang pengurus rusun, ruang serbaguna, warung dan sarana penunjang lainya. Sedangkan untuk lantai dua sampai lantai lima digunakan untuk tempat hunian. Biaya sewa 
dibedakan berdasarkan letak unit rusun penyewa di lantai I harus membayar Rp.126.000 per bulan, lantai II Rp. 120.000 per bulan, lantai III Rp. 114.000 per bulan, lantai IV Rp.108.000 per bulan dan lantai V Rp. 102.000/bulan. Harga sewa tersebut diatas belum termasuk biaya rekening listrik, air dan gas yang menyesuaikan dengan pola penggunaan penyewa. Disamping itu terdapat iuran Rp. 1.000 setiap bulan, untuk pemeliharaan lingkungan dan bangunan.
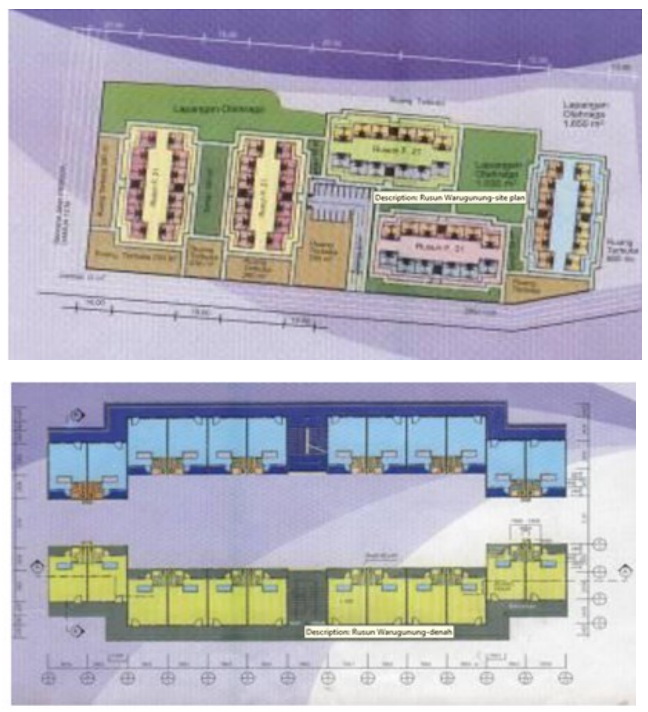

Gambar 2. Layout Plan dan Denah Twin Blok Rusunawa Warugunung (Sumber: Bappeko Surabaya, 2014)

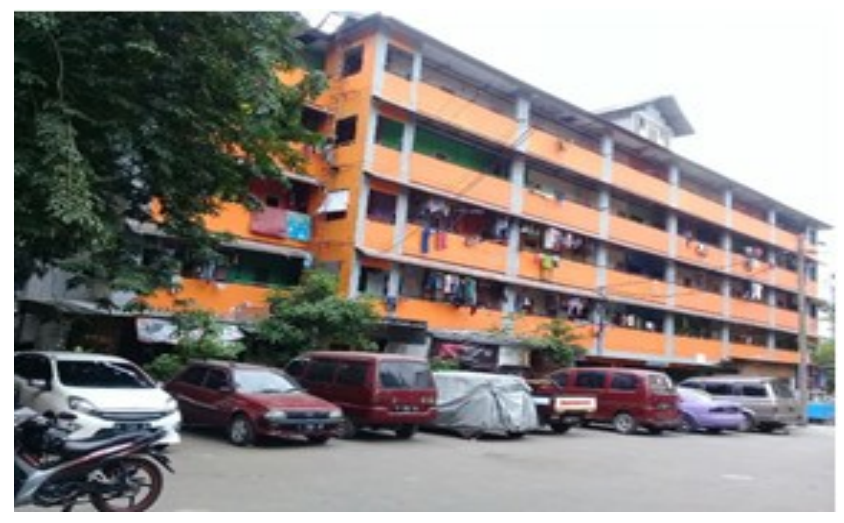

Gambar 3. Kondisi Bangunan Rusunawa Warugunung (Sumber: Dokumentasi Survei, 2018)

Unit rusun di Rusunawa Warugunung difasilitasi dengan listrik 900kwh, air bersih (PDAM), sambungan gas. Kondisi unit rusun pada walnya hanya terdiri dari satu ruang besar dan kamar mandi di bagian belakang. Selain untuk tempat tinggal beberapa penghuni juga membuka usaha warung. Untuk memisahkan ruang, sebagian penghuni menggunakan perabot namun ada juga yang dibatasi dengan triplek. Beberapa keluarga lebih memilih untuk tidak meletakkan perabot sebagai pembatas ruang karena mereka merasa ruang yang sudah kecil tersebut jika diberi pembatas akan terasa semakin sempit dan atau kecil untuk beraktivitas.

\subsection{Identifikasi Karakteristik Penghuni}

Secara umum karakteristik penghuni rusunawa sangat beragam. Berdasarkan identifikasi usia kepala keluarga didapatkan data bahwa sebagian besar berusia lebih dari 50 tahun, sebanyak $54 \%$. Kepala keluarga yang berusia antara 40-50 tahun sebanyak $35 \%$, dan yang berusia $30-40$ tahun sebanyak $11 \%$. Identifikasi penghuni berdasarkan tingkat Pendidikan kepala keluarga menunjukkan bahwa sebanyak $73 \%$ berpendidikan setingkat sekolah menengah atas. Masih terdapat sebanyak $11 \%$ yang berpendidikan setara dengan sekolah dasar dan $13 \%$ berpendidikan sekolah menengah pertama. Terdapat $3 \%$ penghuni yang berpendidikan terakhir setingkat sarjana.

Identifikasi penghuhi berdasarkan jenis pekerjaan dibedakan menjadi 3 (tiga) ketegori yaitu tetap (pegawai negeri), tetap (pegawai swasta) dan tidak tetap (buruh, pedagang, sopir). Hasil survei menunjukkan bahwa sebagian besar kepala keluarga bekerja sebagai pekerja tetap swasta terutama pada industri di sekitar rusun. Terdapat $78 \%$ kepala keluarga bekerja sebagai pegawai swasta, hanya 3\% yang merupakan pegawai negeri dan $19 \%$ bekerja pada sektor informal.

Identifikasi penghuni berdasarkan daerah asal kepala keluarga dikategorisasikan menjadi 4 (empat) yaitu dari Kota Surabaya, Jawa Timur (luar Kota Surabaya), Jawa (luar Jawa Timur) dan dari luar Jawa. Hasil survei menunjukkan bahwa hanya sebanyak $24 \%$ penghuni berasal dari Kota Surabaya, sebanyak $73 \%$ berasal dari sekitar Jawa Timur dan 3\% berasal dari luar Jawa Timur yaitu Bandung. Hasil survei juga mengidentifikasi status kependudukan (KTP) penghuni rusun dalam dua kategori yaitu dari Kota Surabaya dan luar kota. Sebanyak $70.3 \%$ penghuni merupakan penduduk Kota Surabaya, dan $29.7 \%$ penduduk luar Kota Surabaya.

Berdasarkan identifikasi tempat tinggal sebelumnya, hasil survei menunjukkan bahwa sebanyak $51 \%$ tinggal di Kota Surabaya, sebanyak $49 \%$ tinggal di luar Kota Surabaya baik dari sekitar Jawa Timur maupun luar Jawa Timur. Berdasarkan identifikasi lama tinggal hasil survei menunjukkan bahwa penghuni tinggal cukup lama di Rusunawa Warugunung. Sebanyak $8 \%$ tinggal lebih dari 20 tahun dan 33\% tinggal antara $11-20$ tahun. Sebanyak 31\% penghuni tinggal antara 1-5 tahun dan sebanyak $28 \%$ tinggal antara 6-10 tahun. Hasil survei terhadap komposisi jumlah penghuni rusun tiap unit dikelompokkan menjadi tiga kategori yaitu unit rusun dengan 1-2 orang penghuni, 3-4 orang penghuni dan lebih dari 4 orang penghuni. Berdasarkan kategorisasi tersebut terdapat $86 \%$ unit rusun yang ditempati oleh 3-4 orang penghuni, sebanyak $11 \%$ dihuni oleh lebih dari 4 orang dan hanya $3 \%$ dihuni oleh 1-2 orang. 


\subsection{Identifikasi Faktor Kepuasan Tinggal di Rusunawa}

Hasil penelitian sebelumnya menunjukkan beragam faktor yang memoengaruhi tingkat kepuasan penghuni rusunawa. Diantara faktor tersebut adalah (1) faktor lokasi yang berkaitan dengan kedekatan / keterjangkauan lokasi dengan beragam fasilitas kota, (2) faktor ekonomi yang berkaitan dengan keterjangkauan harga sewa dan biaya operasional bulanan, (3) faktor teknis yang berkaitan dengan desain, luasan unit kelengkapan fasilitas (4) faktor pengelolaan terkait perawatan, lembaga pengelola (5) faktor sosial berkaitan dengan hubungan dengan penghuni lain. Hasil penelitian ini dijabarkan dengan pengkategorisasian yang relevan dengan kondisi pada Rusunawa Warugunung.

Lokasi rusun yang berdakatan dengan beragam pabrik tempat penghuni bekerja menjadikan penghuni puas, dimana sebanyak $35 \%$ menyatakan sengat setuju dan $59.5 \%$ menyatakan setuju terkait kedekatan dengan tempat kerja. Hanya $5.4 \%$ menyatakan kurang setuju dan tidak setuju. Berdasarkan kedekatan dengan sekolah hasil survei menunjukkan bahwa hanya $10.8 \%$ menyatakan kurang setuju dan sisanya $98.2 \%$ menyatakan setuju dan sangat setuju bahwa lokasi rusun berdekatan dengan fasilitas pendidikan.

Faktor kedua yang diidentifikasi adalah faktor ekonomi yang berkaitan dengan keterjangkauan terhadap harga sewa dan biaya operasional. Dengan harga sewa lantai I Rp.126.000, lantai II Rp. 120.000, lantai III Rp. 114.000, lantai IV Rp.108.000 dan lantai V Rp. 102.000/bulan peghuni secara tidak keberatan dengan tarif tersebut, termasuk dengan tarif operasionalnya. Penghuni Rusunawa Warugunung menyepakati bahwa harga sewa unit rusun sangat terjangkau dimana sebanyak $97.3 \%$ menyatakan setuju dan sangat setuju. Hanya $2.7 \%$ yang menyatakan tidak setuju dikarenakan alasan pengelolaan yang kurang optimal. Identifikasi terhadap keterjangkauan biaya operasional menunjukkan data yang sejalan dengan respon terhadap harga sewa per bulan.

Berkaitan dengan faktor teknis bangunan diidentifikasi melalui kualitas desain (bangunan), luasan unit rusun, ketersediaan ruang terbuka hijau dan ketersediaan fasilitas penunjang. Secara umum penghuni merasa kondisi bangunan yang cukup baik untuk mengakomodasi aktivitas dan kebutuhan penghuni (gambar 4 dan 5). Sebanyak 10.8\% menyatakan penghuni sangat setuju dan sebanyak $70.3 \%$ menyatakan setuju bahwa desain bangunan rusun tergolong baik. Terdapat $18.9 \%$ penghuni menyatakan desain kurang optimal, dikarenakan kondisi bangunan yang mulai rusak (gambar 6). Respon terhadap luasan unit rusun menunjukkan sebanyak $32.4 \%$ menyatakan luasan unit yang kurang memadai. Kelompok ini mendasarkan pendapatnya pada sempitnya unit rusun yang hanya berukuran $4 \times 6$ meter. Sebanyak $67.6 \%$ menyatakan luasan unit rusun cukup mengakomodasi kebutuhan ruang keluarganya.
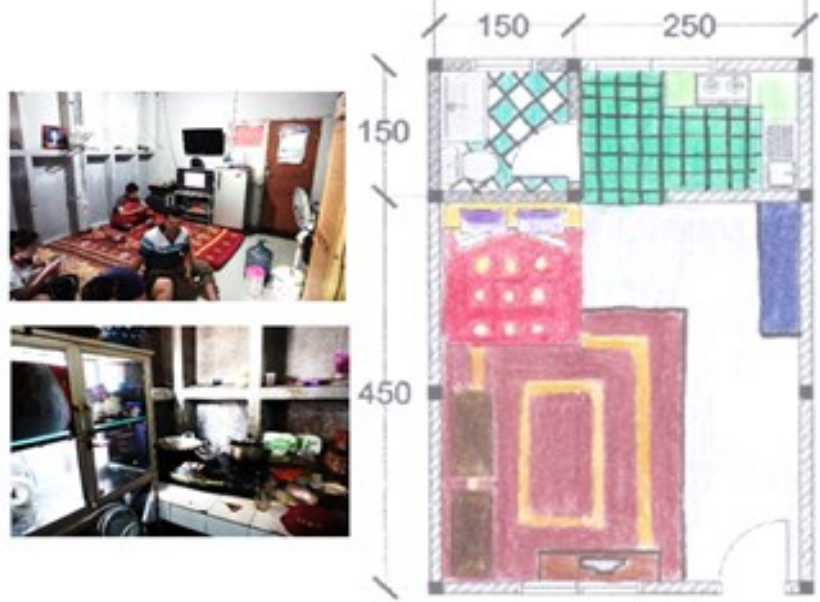

Gambar 4. Kondisi unit rusun di blok Podang Rusunawa Warugunung (Sumber: Dokumentasi Survei, 2018)

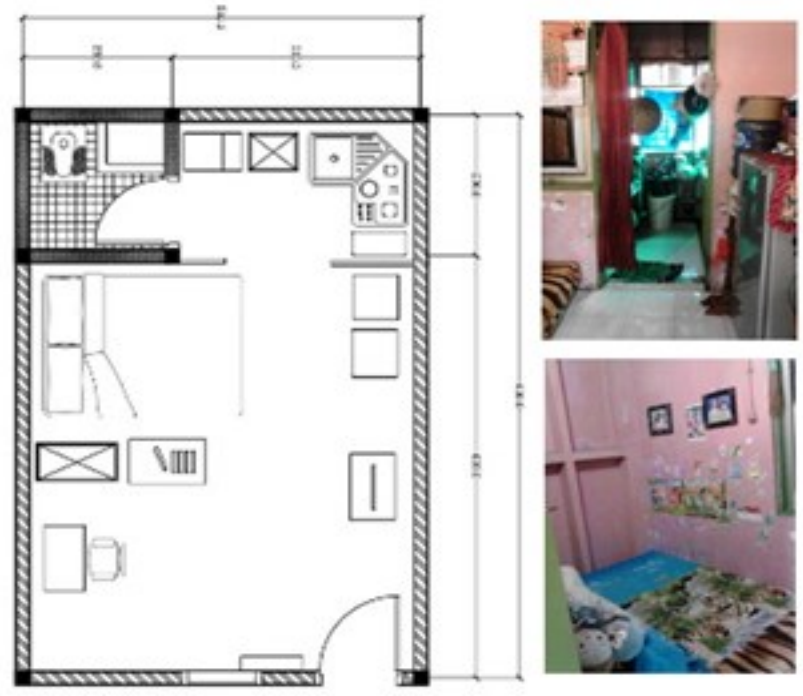

Gambar 5. Kondisi unit rusun di blok Jalak Rusunawa Warugunung (Sumber: Dokumentasi Survei, 2018)
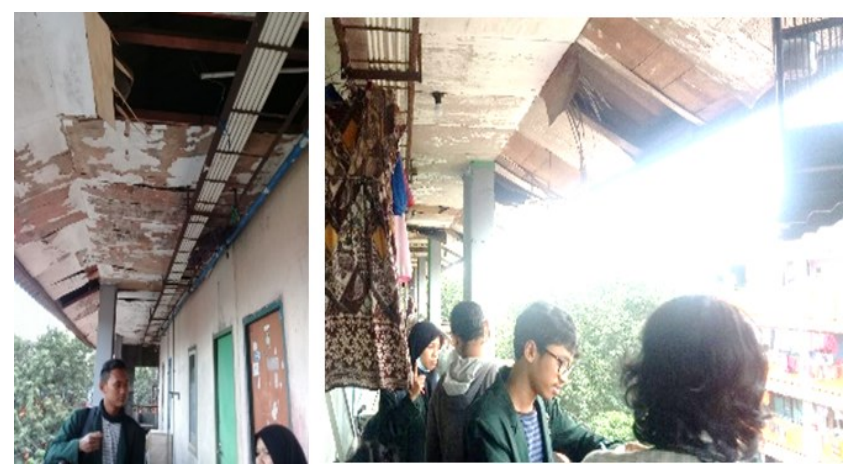

Gambar 6. Beberapa kerusakan elemen bangunan Rusunawa Warugunung (Sumber: Dokumentasi Survei, 2018) 
Berkaitan dengan ketersediaan fasilitas pendukung berupa ruang terbuka hijau dan fasilitas lain, secara umum penghuni menyatakan kecukupan ketersediaannya, hanya sebagian kecil yang menyatakan kurang memadai. Identifikasi terhadap faktor pengelolaan rusun menunjukkan bahwa kinerja pengelolaan dan perawatan bangunan masih perlu ditingkatkan. Penghuni masih merasa belum terlayani dengan baik oleh pengelola, berdasarkan respon kuesioner yang menyatakan $27 \%$ kurang puas dengan kinerja pengelola dan $51.4 \%$ kurang puas terhadap perawatan bangunan. Bahkan $8.1 \%$ menyatakan tidak puas dengan perawatan rusun. Identifikasi terhadap kehidupan sosial bertetangga di Rusunawa Warugunung, hasil penelitian ini menunjukkan kondisi yang kondusif. Sebanyak $46 \%$ menyatakan sangat setuju dan $51 \%$ menyatakan setuju bahwa hubungan baik dengan tetangga menjadikan mereka betah dan puas tinggal di rusun.

\subsection{Identifikasi Faktor Kepuasan Tinggal di Rusunawa}

Perumusan faktor yang mempengaruhi kepuasan tinggal penghuni Rusunawa dilakukan dengan analisis tiangulasi. Dengan mendiskusikan hasil temuan dilapangan berdasarkan rumusan teori dan penelitian terdahulu yang relevan, maka dapat dirumuskan faktor yang mempengaruhi kepuasan dan ketidakpuasan penghuni secara mendalam beserta alasannya (lihat tabel 1).

Tabel 1. Analisis Trangulasi Faktor Kepuasan Tinggal di Rusunawa

\section{Preferensi menurut penghuni \\ Rumusan teori dan hasil penelitian terdahulu}

1. Kedekatan lokasi terhadap lokasi kerja fasilitas pendidikan, fasilitas kesehatan dan fasilitas ekonomi direspon positif oleh karena lokasi yang strategis dan mudah dijangkau memudahkan (efektif dan efisien) dalam melakukan aktivitas sehari-hari.

2. Keterjangkauan terhadap harga sewa dan biaya operasional, penghuni menyatakan puas karena harga dan biaya yang mudah (terjangkau) dengan kemampuan.

3. Desain dan luasan unit rusun yang hanya berukuran $21 \mathrm{~m}^{2}$ menjadikan setiap rumah tangga tidak dapat leluasa beraktivitas di dalam rumah penghuni menunjukkan respon yang kurang puas. Banyaknya kerusakan elemen bangunan yang perlu segera diperbaiki karena membahayakan. Namun penghuni mereka tetap bertahan tinggal.

4. Ketersediaan ruang terbuka hijau dan fasilitas umum, secara umum penghuni sepakat bahwa kedua variabel tersebut menjadikan mereka puas tinggal di rusun.

5. Pengelola dianggap kurang responsif menanggapi beragam keluhan penghuni terutama terkait kerusakan bangunan sehingga kinerja perawatan bangunan menjadi lambat yang menjadikan terjadi kerusakan di banyak bagian rusun. Penghuni merasa kurang puas dengan kinerja pengelola.

6. Kondisi kehidupan sosial yang kondusif menjadikan penghuni betah tinggal karena sudah merasa seperti satu keluarga.

Sintesa hasil diskusi (faktor yang mempengaruhi kepuasan tinggal di Rusun)

1. Faktor lokasi berpengaruh terhadap kepuasan tinggal di rusun karena lokasi yang berdekatan dengan tempat kerja dan strategis dengan beragam fasilitas kota.

2. Faktor ekonomi terkait keterjangkauan harga sewa dan biaya operasional bulanan berpengaruh terhadap kepuasan tinggal di rusun, karena sebagian merupakan masyarakat berpenghasilan rendah.

3. Faktor teknis bangunan yang berpengaruh adalah ketersediaan RTH dan fasilitas umum yang memudahkan melakukan aktivitas keseharian.

4. Faktor kehidupan sosial berpengaruh signifikan terhadap kepuasan tinggal, karena mereka sudah seperti keluarga dengah hubungan sosial yang baik. 


\section{KESIMPULAN}

Penelitian ini merumuskan beberapa faktor yang mempengaruhi kepuasan tinggal penghuni rusunawa yakni diantaranya (1) Faktor lokasi berpengaruh terhadap kepuasan tinggal di rusun karena lokasi yang berdekatan dengan tempat kerja dan strategis dengan beragam fasilitas kota (2) Faktor ekonomi terkait keterjangkauan harga sewa dan biaya operasional bulanan berpengaruh terhadap kepuasan tinggal di rusun, karena sebagian merupakan masyarakat berpenghasilan rendah (3) Faktor teknis bangunan yang berpengaruh adalah ketersediaan RTH dan fasilitas umum yang memudahkan melakukan aktivitas keseharian, dan (4) Faktor kehidupan sosial berpengaruh signifikan terhadap kepuasan tinggal, karena mereka sudah seperti keluarga dengah hubungan sosial yang baik.

Selain merumuskan faktor yang mempengaruhi kepuasan tinggal, penelitian ini juga mengidentifikasi aspek yang masih perlu peningkatan agar kepuasan penghuni semakin baik yaitu diantaranya (1) Faktor teknis bangunan terkait desain dan luasan unit rusun sehingga kenyamanan tinggal lebih optimal. Meskipun penghuni masih tetap bertahan tinggal namun disain dan luasan unit rusun memerlukan penyesuaian yang lebih baik; dan (2) Faktor pengelolaan masih membutuhkan perhatian besar bagi Pemerintah Kota Surabaya mengingat usia kinerja bangunan yang menurun dan keterbatasan sumber daya manusia pengelola rusun. Penelitian ini merekomendasikan kajian secara menyeluruh untuk mengetahui secara lebih komprehensif faktor yang mempengaruhi kepuasan tinggal penghuni rusunawa di Kota Surabaya. Berdasarkan temuan penelitian ini maka Pemerintah Kota Surabaya perlu melakukan perbaikan pada elemen-elemen bangunan rusunawa untuk menjamin kenyamanan dan keamanan tinggal. Selain itu sistem pengelolaan bangunan juga perlu dioptimalkan agar dapat lebih baik dalam memberikan pelayanan kepada penghuni.

\section{DAFTAR PUSTAKA}

Dafrimon, D., \& Tanzil, G. (2012). Kualitas Kepuasan Penghuni Rumah Susun Perum Perumnas Palembang. PILAR, 7(2). Retrieved from https://www.jurnal.polsri.ac.id/index.php/pilar/artic le/view/387

Greene, M., \& Ortúzar, J. D. D. (2002). Willingness to Pay for Social Housing Attributes: A Case Study from Chile. International Planning Studies, 7(1), 55-87. doi: 10.1080/13563470220112607

Hidayati, M. K. (2017). Tingkat Kepuasan Penghuni Rusunawa Terhadap Fisik Dan Lingkungan Rusunawa Di Surakarta (Thesis, Universitas Muhammadiyah Surakarta). Retrieved from http://eprints.ums.ac.id/55961/
Hui, E. C. M. (1999). Willingness to Pay for Better Housing in Hong Kong: Theory and Evidence (of Dwelling Space). Urban Studies, 36(2), 289-304. doi: 10.1080/0042098993619

Irkham, N., \& Utomo, C. (2017). Analisis Penetapan Harga Sewa Berdasarkan Tingkat Subsidi Tertentu Rusun Grudo Kota Surabaya. Jurnal Teknik ITS, 6(1), C50-C55-C55. doi: 10.12962/j23373539.v6i1.22009

Mohit, M. A., \& Raja, A. M. M. A.-K. (2014). Residential Satisfaction-Concept, Theories and Empirical Studies. Planning Malaysia, 12(3). doi: 10.21837/pmjournal.v12.i3.131

Moleong, L. J. (2000). Metodologi penelitian kualitatif. Bandung: Remadja Karya.

Paris, D. E., \& Kangari, R. (2005). Multifamily Affordable Housing: Residential Satisfaction. Journal of Performance of Constructed Facilities, 19(2), 138-145. doi: 10.1061/(ASCE)08873828(2005)19:2(138)

Rahman, S., \& Rahdriawan, M. (2017). Pengaruh Kondisi Perumahan terhadap Kepuasan Penghuni di Perumahan Grand Tembalang Regency Semarang. Jurnal Pengembangan Kota, 5(1), 69-77-77. doi: 10.14710/jpk.5.1.69-77

Rapoport, A. (2016). Human Aspects of Urban Form: Towards a Man-Environment Approach to Urban Form and Design. Elsevier.

Setiadi, H. A. (2014). Persepsi Tingkat Kepuasan Penghuni Terhadap Atribut Rumah Susun Sewa Kemayoran. Jurnal Sosial Ekonomi Pekerjaan Umum, 6(1). Retrieved from http://jurnalsosekpu.pu.go.id/index.php/sosekpu/ article/view/19

Sofyan, M. Y. (2006). Pengadaan Rusun Sewa Sebagai Alternatif Permukiman Pekerja Industri di Desa Warugunung Karang Pilang Surabaya. SMARTek, 4(3). Retrieved from http://jurnal.untad.ac.id/jurnal/index.php/SMARTE K/article/view/439

Sugiyono. (2010). Metode Penelitian Kuantitatif dan Kualitatif R\&B. Jakarta: Alfabeta.

Tondok, M. S., Oesmani, I. V., \& Tonny. (2012). Rumahku Tidak Menapak Bumi: Rumah Susun Penjaringan Sari. 1-16. Surabaya: Universitas Surabaya.

Turner, J. F. C. (1976). Housing by People: Towards Autonomy in Building Environments. Marion Boyars.

Widiastomo, Y. (2014). Pengaruh Kualitas Rumah dan Lingkungan terhadap Kepuasan Penghuni dan Kecenderungan Berpindah di Perumnas Bukit Sendangmulyo Semarang. Jurnal Pembangunan Wilayah \& Kota, 10(4), 413-424. doi: 10.14710/pwk.v10i4.8168

Zahro, R. I. (2016). Pengaruh kualitas pelayanan dinas pengelolaan bangunan dan tanah terhadap 
kepuasan penyewa rumah susun sederhana sewa (rusunawa) waru gunung karang pilang surabaya. Kebjakan Dan Manajemen Publik, 4(3), 186-196. 